a few Slate-colored Juncos, abundant Chipping Sparrows (young, nest with eggis), a few Clay-colored Sparrows (young. nest with eggs), many White-throated Sparrows (common -nest with eggs found), three Swamp Sp:arrows (two adults feeding a fledgling), and abundant Song Sparrows. We had hoped for a better sparrow list also.

Without exception the species observed are summer residents, on their breeding grounds. It will be noted that some of the species on our list are breeding well beyond the breeding ranges given for them in the standard handbooks.

\section{BITTERN BEHAVIOR} By Joyce Dew

Saskatchewan Museum of Natural History

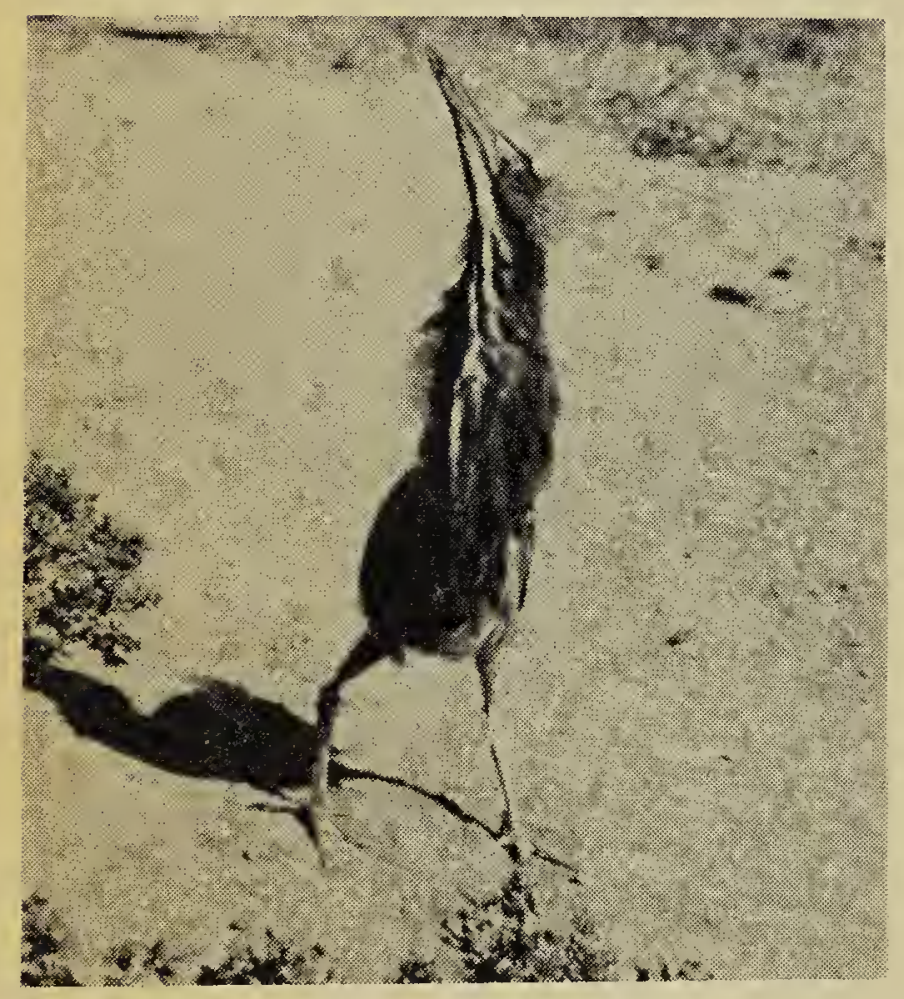

AMERICAN BITTERN

The prototype of a bittern, standing upright and motionless, well camouflaged in the reeds, was firm in my mind. It came somewhat as a shock then, when I saw my first bittern* behaving in a bittern-like manner in very unbittern-like surroundings. Certainly this bird could not have been more noticeable. This was contrary to all I had been led to expect from its "camouflage" behavior. The place was a puddle of water completely devoid of cover beside old No. 1 highway west of Moose Jaw. The bird stood upright and alert in the middle of the puddle while I sped past, slowed the car down, shifted it into reverse, came alongside and sat and stared. The bird had one eye turned toward me and the two of us remained completely motionless for some seconds. Then the bird leaned forward, took several siteps tcward shore, assumed a moticnless upright position for several seconds, took several more steps, pause again. Once on shore it tcok several steps, assumed its motionless upright positicn then with no apparent haste flew away. Fred Lahrman of the IMseum staff reports having seen a bittern behave in like manner. When caught off guard in the open it stood bolt upright beside a water trough. [Ed.].

* American Bittern (Bctaurus lentiginosus

\section{MORE BLACK DUCK RECORDS}

Since the publication of Lucy Murray's article on the Black Duck in Siskatchewan (Blue Jay, XVI: 109-111), the following records of the cccurrence of the Black Duck in this province have been brought to our attention.

It should also be noted that two of the four Black Ducks banded at Yorkton, 1945, were banded by Stuart Houston, and two by J. H. Wilson (see Blue Jay, XVI, p. 109.).

Ducks Unlimited: Adult male Black Ducks banded by biologist Tom Sterling at Pel Lake, Wynyard, as follows: July 15,1955 (1), Aug. 16, 1955 (1), July 23, 1956 (1), July 9, 1957 (2), July 19, 1957 (7), July 11, 1958 (4), July 23, 1958 (2). Also one adult male banded at Kutawagan Lake, Wynyard, by Tom Sterling, July 9, 1958, and one adult male (banded in Wayne County, Michigan) trapped and released by him July 23, 1956. The fact that all Black Ducks banded by Sterling were adult males is probably due to their being bander in the drive banding of flightless ducks on the two lakes that have become notable concentration areas for mculters. - B. W. Cartwright.

Canadian Wildlife Service: Black Ducks banded as fcllows- 1950 ( 3 adult males, 1 adult female), 1952 ( 2 adult males), 1955 ( 2 sex and age unknown), 1956 (1), 1958 (1 Mculting adult drake, caught at Bea ufield Slough, 23 miles north of Kindersley, July 2); s $\mathrm{pring}$ report by Tom Sterling of Ducks Unlimited of a Black Duck flying with a Mallard female east cf Saskatoon in April or May, 1958; fall (Sept.-Oct.) records for Kindersley are as follows-1956 ( 2 flying adult drakes caught in bait traps), 1957 ( 1 adult drake in bait trap and 1 shot by hunter), 1958 ( 1 adult drake in bait trap and 2 seen in Teo Lake Community Pasture: one adult drake Mallard $X$ Black Duck hybrid caught in bait traps, Oct. 8).-J. B. Gollop, Alex Dzubin.

Maurice Street, Nipawin: 2 birds seen May 16, 1947; single birds seen on May 18, 1951 , and May 22, 1952; also noted at Candle Lake, July 31, 1944 ( 2 males).

Bill Anaka, Spirit Lake: One observed September 26, 1954. 